\title{
PENGARUH PERSEPSI KEAMANAN DAN PRIVASI TERHADAP KEPUASAN DAN KEPERCAYAAN KONSUMEN ONLINE
}

\author{
Bondan Satrio Kinasih \\ Fakultas Ekonomi Universitas Islam Indonesia \\ e-mail: bondan.kinasih@gmail.com \\ Albari \\ Fakultas Ekonomi Universitas Islam Indonesia \\ e-mail: albari@uii.ac.id
}

\begin{abstract}
Customer satisfaction is a critical objective in marketing activities. Satisfaction as a dynamic concept is necessary but not sufficient in maintaining long-term relationship between the company as the provider of goods and services and the customer. To facilitate such a relationship there exist the need to maintain trust as a main catalyst especially when it deals with virtual businesses. Many costumers, especially those of traditional buyer, have a low trust on online business particularly related to the safety and privacy of information when they engage via Internet facilities in comparison to the offline-traditional businesses. The relationship between those factors, namely satisfaction, trust, safety and privacy, will be used as the model in this research. Perceived safety and privacy will be treat as antecedent variables, while satisfaction will be used as mediating variable, and perceived trust on online business will be utilized as an endogenous variable. The research collecting data from various individuals (96 samples) whose already have experience with online business selected based on the convenience sampling technique. The result shows positive relationships between perceived safety and privacy on customer satisfaction on online business. Both variables together with customer satisfaction is also shows positive relationship on customer trust when dealing with online businesses.
\end{abstract}

Keywords: perception of security, privacy perceptions, satisfaction, trust.

\begin{abstract}
Abstrak
Dalam konteks pemasaran capaian kepuasan konsumen menjadi salah satu tujuan dilakukannya kegiatan pemasaran. Namun kepuasan saja mungkin tidak cukup untuk membangun hubungan jangka panjang pelanggan terhadap penyedia layanan. Diperlukan aspek lain seperti kepercayaan sebagai katalis penting, terutama jika dikaitkan untuk membangun hubungan bisnis online. Apalagi konsumen cenderung masih kurang percaya dengan keamanan dan privasi mereka ketika melakukan hubungan melalui internet dibandingkan dengan transaksi melalui toko offline. Keterkaitan keempat aspek tersebut digambarkan dalam model penelitian ini dengan menetapkan persepsi keamanan dan privasi sebagai variabel anteseden, kepuasan sebagai variabel mediator, dan kepercayaan konsumen online sebagai variabel endogen. Subyek penelitian melibatkan sampel konsumen yang sudah pernah melakukan transaksi secara online sebanyak 96 orang dan sampel diperoleh melalui teknik convenience sampling. Hasil penelitian menunjukkan adanya pengaruh positif persepsi keamanan dan privasi terhadap kepuasan konsumen online. Kedua variabel tersebut bersama-sama dengan kepuasan juga bisa berpengaruh positif terhadap kepercayaan konsumen online tersebut.
\end{abstract}

Kata kunci: persepsi keamanan, persepsi privasi, kepuasan, kepercayaan.

\section{PENDAHULUAN}

Internet dan website telah menjadi perkembangan yang paling menarik di bidang teknologi informasi, komunikasi, dan pe- masaran dalam beberapa tahun terakhir. Saluran informasi dan komunikasi menjadi berkembang sangat cepat dan mudah seiring dengan perkembangan teknologi. Sementara itu 
dalam lingkup pemasaran pemanfaatan akses internet ini salah satunya dalam kegiatan $e$ commerce. Dengan peningkatan akses internet, penggunaan e-commerce sebagai 'tempat' untuk menjual berbagai produk menjadi sesuatu yang menjanjikan bagi para produsen di berbagai belahan dunia.

Secara sederhana e-commerce diartikan sebagai tawaran perusahaan atau situs untuk transaksi dan fasilitas penjualan produk dan jasa secara online (Kotler and Killer, 2009). Sementara itu Tjiptono (2000) mengelompokkan lingkup e-commerce menjadi 5 perspektif berikut: (1) online purchasing, yang berkaitan dengan sistem pembelian dan penjualan dan informasi melalui internet dan jasa online lain nya, (2) digital communication, berhubungan dnegan sistem pengiriman informasi digital, produk, jasa dan pembayaran online, (3) service, berupa suatu sistem yang berupaya menekan biaya, menyempurnakan kualitas produk dan informasi instan terkini, dan meningkatkan kecepatan penyampaian jasa, (4) business process, berhubungan dengan sistem untuk otomisasi transaksi bisnis dan aliran kerja, dan (5) market-on-one, lebih banyak berupa sistem untuk proses customization produk dan jasa yang diadaptasikan pada kebutuhan dan keinginan setiap pelanggan secara efisien.

Ada banyak kelebihan dan keuntungan melakukan bisnis secara online. Chung and Shin (2008) menunjukkan beberapa keuntungan terjadinya transaksi dengan e-commerce antara konsumen dan bisnis dapat berupa kenyamanan, penghematan, seleksi, personalisasi, dan informasi. E-commerce juga menawarkan kepada mereka pilihan yang lebih baik untuk melakukan transaksi secara nyata. Bahkan Rofiq (2007) merinci banyak keuntungan transaksi bagi pembeli dan penjual melalui e-commerce. Keuntungan pembeli tersebut di antaranya adalah lebih cepat/nyaman/mudah dalam pembelian, pilihan produk dan harga, umpan balik terhadap supplier, vendor dan biro iklan, akses informasi, dan ketersediaan layanan konsumen. Sedangkan keuntungan penjual di antaranya berkaitan dengan efisiensi biaya dan waktu dalam proses pemesanan sampai distribusi, meningkatnya daya saing, mengatasi hambatan global dan pemasaran, manajemen informasi dan komunikasi, serta mengidentifikasi dan mengembangkan pasar baru.
Berkaitan dengan bisnis melalui internet atau online ini menurut Flavia'n and Guinalı'u (2006) konsumen masih cenderung kurang percaya segala sesuatu tentang terjamin dan normalnya transaksi melalui internet dibandingkan dengan transaksi melalui toko offline Hal ini karena: (1) dalam transaksi online konsumen tidak memiliki interaksi fisik dengan penjual, sehingga tidak dapat mengevaluasi secara efektif adanya penawaran produk atau memeriksa identitas penjual, (2) pembayaran biasanya dilakukan dengan kartu kredit sebelum penyerahan barang atau jasa, sehingga memungkinkan adanya kecurangan dalam penggunaan data keuangan konsumen, (3) adanya kemungkinan produk yang diterima bukan seperti yang diminta, (4) adanya kesulitan dalam membuat pengaduan kepada perusahaan yang tidak memiliki kantor secara fisik atau kantor yang berada di negara lain, (5) adanya fakta bahwa beberapa konsumen terkendala dalam mengoperasikan internet, sehingga mereka tidak mampu membedakan alternatif-alternatif yang ada, (6) meningkatnya masalah dengan spam, (7) laporan secara kontinyu adanya serangan hacker dan virus, dan (8) adanya kerangka hukum yang tidak lengkap, heterogen dan tidak efektif. Karena itu perkembangan tingkat kepercayaan melalui internet lebih sulit daripada melalui saluran tradisional.

Kepercayaan konsumen online dapat dibentuk atau ditingkatkan melalui kepuasan. Menurut Chung and Shin (2009) dalam kontek layanan secara fisik kepuasan pelanggan merupakan syarat penting untuk mencapai kinerja keuangan. Demikian pula pada lingkup e-commerce pelanggan dapat hilang jika mereka tidak dapat mengakses website atau jika pengalaman membuktikan layanan bisnis tidak memuaskan. Menurut Jin and Park (2006) studi sebelumnya menunjukkan bahwa kepuasan pelanggan di toko online terhadap e-tailer tergantung terutama pada evaluasi berbagai atribut kinerja, yang di antaranya adalah pada aspek keamanan dan privasi yang dirasakan oleh konsumen. Jin and Park juga membuktikan bahwa selain terhadap kepuasan, persepsi keamanan dan privasi juga dapat berpengaruh positif terhadap kepercayaan. Atau dengan kata lain, persepsi keamanan dan privasi dapat menjadi aspek penting yang dapat mempe- 
ngaruhi kepuasan dan kepercayaan konsumen dalam bertransaksi bisnis secara online .

Persepsi keamanan biasa dikaitkan dengan ancaman yang menciptakan keadaan, kondisi, atau peristiwa yang berpotensi menyebabkan kesulitan ekonomi melalui sumber data atau jaringan yang mengalami kerusakan pengumpulan dan modifikasi data, penolakan layanan, dan/atau penipuan dan penyalahgunaan wewenang (Armesh et al., 2010). Sementara itu menurut Roca et al. (2009) persepsi privasi berhubungan dengan perasaan konsumen tentang adanya kemungkinan bahwa perusahaan online mengumpulkan dan menggunakannya data tentang individu secara tidak tepat.

Jika merujuk pada pengertian persepsi keamanan dan privasi di atas, maka persepsi konsumen online pada saat ini masih cenderung terlihat negatif. Karena itu upaya mempertahankan dan memperbaiki kualitas layanan dalam bertransaksi, terlebih dalam transaksi bisnis menggunakan layanan internet/online atau e-commerce akan membuat konsumen merasa lebih terpuaskan dan dapat menciptakan sikap kepercayaan konsumen. Oleh sebab itu dengan mempelajari pentingnya keterkaitan keempat aspek tersebut di atas akan dapat membantu perkembangan bisnis melalui layanan online atau e-commerce pada saat ini, terutama dalam rangka untuk membangun potensi hubungan jangka panjang antara pengusaha online dengan konsumennya. Studi akan lebih difokuskan pada usaha untuk mengungkap pengaruh positif persepsi keamanan dan privasi terhadap kepuasan dan kepercayaan konsumen online.

\section{KAJIAN PUSTAKA}

Kajian pustaka ini dimaksudkan untuk mendokumentasikan dan mengkaji berbagai teori, konsep, anggapan dasar serta hubungan antara berbagai variabel yang digunakan untuk pemecahan masalah.

\section{Persepsi keamanan (Perceived security)}

Persepsi keamanan diartikan sebagai persepsi konsumen atas keamanan dalam melakukan transaksi e-commerce (Eid, 2011). Sedangkan Flavia'n and Guinalı'u (2006) mengartikan persepsi keamanan sebagai kemungkinan kepercayaan subjektif yang dimiliki konsumen bahwa informasi pribadi mereka (dalam aspek perdata dan moneter) tidak akan dilihat, disimpan, dan dimanipulasi oleh pihak lain selama dalam perjalanan dan penyimpanan, sehingga secara secara konsisten menimbulkan harapan kepercayaan diri mereka. Persepsi keamanan juga didefinisikan sebagai ancaman yang menciptakan keadaan, kondisi, atau peristiwa yang berpotensi menyebabkan kesulitan ekonomi melalui sumber data atau jaringan yang mengalami kerusakan, pengumpulan dan modifikasi data, penolakan layanan, dan/atau penipuan dan penyalahgunaan wewenang (Roca et al., 2009; Armesh et al., 2010).

Secara teknis persepsi keamanan akan menjamin integritas, kerahasiaan, otentifikasi dan tanpa pencatatan transaksi (Flavia'n and Guinalı'u, 2006). Menurut Flavia'n and Guinalı'u tersebut integritas suatu sistem informasi mengacu pada kemustahilan dari data yang ditransmisikan atau disimpan akan dapat dimodifikasi oleh pihak ketiga tanpa izin. Kerahasiaan melibatkan data yang hanya dapat dilihat oleh individu yang berwenang. Otentikasi memungkinkan suatu kegiatan tertentu hanya akan dilakukan setelah identifikasi, atau adanya jaminan bahwa identitas hanya digunakan untuk suatu urusan tertentu saja (misalnya situs web). Akhirnya, tanpa pencatatan transaksi (non-repudiation) mengacu pada prosedur yang melindungi individu atau organisasi untuk menyangkal bahwa mereka telah melakukan operasi tertentu (misalnya order pembelian). Menurut Roca et al. (2009) keamanan juga melibatkan penggunaan kemajuan teknis yang dapat mempunyai pengaruh yang positif terhadap niat untuk membeli secara online, seperti kriptografi, tanda tangan dan sertifikat digital yang bertujuan untuk melindungi pengguna dari risiko penipuan, hacking atau "phishing".

Sementara itu menurut Armesh et al. (2010) masih banyak konsumen yang enggan untuk melepaskan informasi kartu kreditnya kepada pedagang online, karena takut kehilangan kontrol atas rekening mereka, sehingga diperlukan evaluasi dalam fitur dan atribut keamanan, yang meliputi kemungkinan: (1) situs tersebut menyediakan enkripsi, (2) situs yang mengharuskan pengguna untuk mengatur akun dengan ID dan password, dan (3) konfirmasi di tampilkan layar setelah selesai proses pembelian untuk memastikan akurasi. Selain itu secara khusus Ahmad and Al 
Zu'bi (2011) menunjukkan pemakaian Secure Socket Layer, yang banyak digunakan di bidang protokoler juga berguna untuk pembayaran kartu kredit secara online. Karena itu, penerapannya perlu dirancang untuk menyediakan: (1) saluran pribadi dan dapat diandalkan dalam komunikasi antara dua entitas, (2) penggunaan Applet Java yang berjalan dalam browser pengguna, (3) penggunaan Personal Identification Number, serta (4) terintegrasinya tanda tangan dan sertifikat digital yang terkait dengan sistem kartu pintar. Menurut Ahmad and $\mathrm{Al}$ Zu'bi tersebut sebuah kombinasi yang menggunakan smart card dan pengakuan biometrik sidik jari menawarkan akses yang lebih aman dan lebih mudah untuk mengontrol komputer daripada metode sandi.

Dalam kaitannya dengan variabel lain Jin and Park (2006) menunjukkan bahwa terdapat pengaruh positif keamanan terhadap kepuasan pelanggan online. Hasil penelitian tersebut juga didukung oleh pembuktian secara empiris dari penelitian-penelitian dari Chung and Shin $(2009,2010)$.

Berdasarkan pembahasan di atas dapat diajukan hipotesis penelitian sebagai berikut:

H1: Persepsi keamanan berpengaruh positif terhadap kepuasan.

Sementara itu Flavia'n and Guinalı'u (2006) membuktikan bahwa persepsi keamanan dapat berkaitan langsung dan positif terhadap kepercayaan. Penelitian yang lain juga telah berhasil memberikan dukungan empiris. Hasil penelitian Roca et al. (2009) menunjukkan bahwa persepsi keamanan dapat berpengaruh positif terhadap kepercayaan konsumen online.

Mendasarkan pada penjelasan di atas maka hipotesis penelitiannya adalah:

H2: Persepsi keamanan berpengaruh positif terhadap kepercayaan.

\section{Persepsi privasi (Perceived Privacy)}

Privas merupakan dimensi penting yang dapat mempengaruhi minat pengguna untuk mengadopsi transaksi berbasis sistem elektronik (Ahmad and Al Zu'bi, 2011). Secara umum privasi didefinisikan sebagai kemampuan individu untuk memperoleh, mengontrol dan memanfaatkan informasi pribadi (Flavia'n and Guinalı'u, 2006). Karena itu dalam konteks internet, privasi berkaitan dengan aspek seperti distribusi, seperti memperoleh atau menggunakan informasi pribadi.

Sementara itu Persepsi privasi berkaitan dengan kemampuan konsumen untuk mengendalikan penyebaran informasi selama transaksi atau perilaku konsumsi konsumen tersebut dari orang lain di sekitarnya (Eid, 2011). Menurut Roca et al. (2009) persepsi privasi adalah suatu kemungkinan bahwa perusahaan online mengumpulkan dan menggunakannya data tentang individu secara tidak tepat. Karena itu pelanggan enggan untuk memasukkan informasi pribadi mereka ketika situs meminta informasi tersebut, karena mereka khawatir tentang pengumpulan dan penyalahgunaan informasi yang dikirim melalui internet dan cara data mereka akan digunakan. Dampaknya adalah konsumen online menjadi ragu untuk mengungkapkan setiap informasi pribadi atau keuangannya kepada perusahaan, sebab mereka merasa bahwa perusahaan bisa membuat penggunaan yang tidak sah atau membocorkan ke organisasi lainnya.

Pengertian yang lebih positif disampaikan oleh Armesh et al. (2010). Menurut Armesh et al. tersebut privasi dalam e-commerce didefinisikan sebagai kesediaan untuk berbagi informasi melalui internet yang memungkinkan terjadinya pembelian. Karena itu fitur yang perlu dievaluasi dalam atribut privasi adalah: (1) penggunaan pernyataan untuk privasi, (2) kebijakan perusahaan dalam penjualan informasi pelanggan kepada pihak ketiga, dan (3) penggunaan pelacak untuk mengumpulkan informasi pribadi. Sementara itu Kassim and Abdullah (2010), yang menyatakan bahwa penanganan privasi perlu mengacu pada perlindungan berbagai jenis data yang dikumpulkan (dengan atau tanpa pengetahuan pengguna) selama interaksi antara pengguna dengan sistem online

Chung and Shin (2010) menyatakan bahwa perlindungan terhadap privasi adalah penting untuk meningkatkan kepuasan. Pen dapat tersebut didukung oleh hasil penelitian empiris dari Jin and Park (2006). Hasil pengujian mereka tersebut menunjukkan adanya pengaruh positif persepsi privasi terhadap kepuasan konsumen online.

Menyimak pembahasan di atas, maka hipotesis penelitiannya adalah:

H3: Persepsi privasi berpengaruh positif terhadap kepuasan. 
Selain terhadap kepuasan, persepsi privasi juga dapat berpengaruh secara langsung dan positif terhadap kepercayaan konsumen online. Pernyataan itu didukung oleh penelitian empiris yang telah dilakukan oleh Flavia'n and Guinalı'u (2006) serta Armesh et al. (2010). Dalam penelitiannya tersebut mereka menghasilkan kesimpulan bahwa persepsi privasi mampu berpengaruh positif terhadap kepercayaan konsumen online Karena itu hipotesis penelitian ini adalah:

H4: Persepsi privasi berpengaruh positif terhadap kepercayaan.

\section{Kepuasan Konsumen (Customer Satisfaction)}

Ahmad and Al Zu'bi (2011) menyatakan kepuasan secara tradisional didefinisikan sebagai kognisi berbasis fenomena. Kognisi biasa dikaitkan terutama dalam hal harapan/paradigma konfirmasi/diskonfirmasi, yang menyatakan bahwa harapan berasal dari keyakinan pelanggan tentang tingkat kinerja bahwa produk/jasa akan diberikan. Kepuasan pelanggan juga berkaitan dengan ukuran dan arah diskonfirmasi, yang menunjukkan selisih antara pasca pembelian dan pasca-penggunaan atau evaluasi kinerja produk/layanan dan harapan yang diadakan sebelum pembelian.

Menurut Jin and Park (2006) pada studi sebelumnya menunjukkan bahwa kepuasan pelanggan di toko online terhadap e-tailer tergantung terutama pada evaluasi berbagai atribut kinerja, yang di antaranya adalah pada aspek keamanan dan privasi. Kepuasan tersebut menjadi penting, karena pada lingkup $e$ commerce pelanggan dapat hilang jika mereka tidak dapat mengakses website atau jika pengalaman membuktikan layanan bisnis tidak memuaskan (Chung and Shin, 2008).

Aplikasi-aplikasi yang disediakan atau fitur-fitur menarik yang disediakan oleh $e$ commerce dapat menyebabkan kepuasan konsumen akan website e-commerce. Pendapat tersebut didukung oleh hasil penelitian Chung and Shin $(2009,2010)$. Mereka berhasil membuktikan bahwa tingkat kepercayaan pelanggan dipengaruhi secara positif oleh kepuasan mereka setelah bertransaksi. Penelitian Chung and Shin (2010) juga menunjukkan tingkat kepuasan yang tinggi dari layanan yang diterima di transaksi online sebelumnya cenderung meningkatkan kepercayaan konsumen.
Dengan demikian hipotesis penelitian yang diajukan adalah:

H5: Kepuasan pelanggan berpengaruh positif terhadap kepercayaan.

\section{Kepercayaan}

Secara umum kepercayaan didefinisikan sebagai keadaan psikologis yang membangun niat untuk menerima kerentanan berdasarkan ekspektasi niat atau perilaku lain (Kassim and Abdullah, 2010). Menurut Kassim and Abdullah tersebut kepercayaan dipandang sebagai faktor yang sangat penting dalam proses pembangunan dan pemeliharaan hubungan, meskipun juga diakui sebagai sulit untuk mengelola. Ketika kepercayaan dikonseptualisasikan sebagai dimensi model penerimaan teknologi, kepercayaan bisa dianggap memiliki pengaruh yang mencolok pada kesediaan pengguna untuk terlibat dalam pertukaran uang secan online dan sensitifitas informasi pribadi. Sulit untuk membayangkan bahwa konsumen akan bertransaksi dengan ritel online tanpa menaruh kepercayaan dasar mereka kepada suatu vendor tertentu (Chung and Shin, 2010).

Sementara itu Jin and Park (2006) mengartikan kepercayaan sebagai keyakinan atau harapan bahwa kata atau janji yang disampaikan oleh pedagang dapat diandalkan (kredibilitas) dan bahwa penjual tidak akan mengambil keuntungan dari kerentanan konsumen (niat baik). Namun bagi Flavia'n and Guinalı'u (2006) dua unsur itu belum cukup untuk membangun kepercayaan. Flavia'n and Guinalı'u menekankan perlunya penyedia layanan online mengembangkan 3 dimensi kepercayaan secara komprehensif, yaitu selain kejujuran (honesty) atau kredibilitas dan niat baik (benevolence), perlu juga mengembangkan dimensi kompetensi (competence). Kejujuran (atau kredibilitas) menunjukkan kepastian konsumen tentang ketulusan dan fakta bahwa bisnis akan memenuhi janji yang dibuatnya. Niat baik (kebajikan) berkaitan dengan kepercayaan konsumen bahwa perusahaan tertarik dan memperhatikan pada kesejahteraan konsumen, dan bahwa mereka tidak berniat untuk menampilkan perilaku yang oportunis, tetapi lebih dimotivasi untuk memenuhi kepentingan bersama. Sedangkan dimensi kompetensi mengacu pada keterampilan dan kemampuan perusahaan yang dirasakan di 
pihak lain. Karena itu, menurut Flavia'n and Guinalı'u (2006) dalam konteks hubungan secara online pengusaha perlu membuktikan dan tidak diragukan untuk bersikap jujur dan bertindak dengan itikad baik, memiliki teknis, keuangan dan sumber daya manusia yang diperlukan untuk menyelesaikan keberhasilan transaksi, seperti ketepatan tanggal pengiriman atau memastikan bahwa setiap rincian data perbankan disimpan dan dijaga kerahasiaannya. Dengan kata lain, bukan hanya soal membuat janji dan memiliki niat baik, tetapi juga memastikan bahwa janji-janji dan niat benarbenar terwujud.

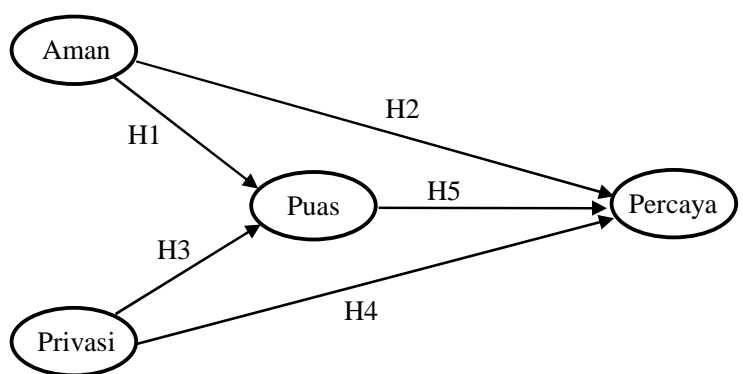

Mendasarkan pada penjelasan variabel dan beberapa hipotesis tersebut di atas, maka kerangka penelitian ini dapat diilustrasikan seperti pada Gambar 1.

\section{METODE PENELITIAN}

Subyek penelitian ini adalah mahasiswa di suatu fakultas di salah satu perguruan tinggi swasta (PTS) yang ada di Yogyakarta yang sudah pernah melakukan transaksi secara online. Sedangkan jumlah sampel ditetapkan sebanyak 96 orang. Jumlah tersebut didasarkan pada asumsi: (1) jumlah dan identitas populasi yang memenuhi kriteria yang ditetapkan tidak diketahui, (2) tingkat signifikansi dugaan sebesar 5\%, dan (3) deviasi sampling maksimal yang bisa ditolerir adalah $10 \%$. Adapun responden penelitian yang dijadikan sampel dipilih dengan memakai teknik pengambilan sampel convinience sampling, yaitu ketika responden sedang berada di kampus fakultas dan PTS yang bersangkutan.

\section{Gambar 1: Model Penelitian}

Tabel 1: Definisi Operasional Variabel Penelitian

\begin{tabular}{|c|c|}
\hline Variabel, pengertian dan indikator & Sumber kajian \\
\hline $\begin{array}{l}\text { Persepsi keamanan adalah persepsi konsumen atas keamanan dalam transaksi } e \text { - } \\
\text { commerce. } \\
\text { - } \quad \text { Tersedianya mekanisme transmisi untuk memastikan informasi penggunanya aman. } \\
\text { - } \quad \text { Tersedianya kapasitas teknik untuk menjamin bahwa data dari konsumen aman. } \\
\text { - } \quad \text { Keamanan keuangan saat melakukan transaksi pembelian di website. } \\
\text { Persepsi privasi adalah persepsi konsumen atas kemampuan untuk mengendalikan } \\
\text { segala informasi yang berkaitan tentang konsumen tersebut dari orang lain di } \\
\text { sekitarnya. } \\
\text { - } \quad \text { Adanya jaminan hukum terhadap perlindungan data konsumen. } \\
\text { - Pengumpulan data pribadi konsumen yang diperlukan untuk aktivitas website } \\
\text { - } \text { Adanya persetujuan dengan konsumen dalam hal penyebaran informasi. } \\
\text { - Kenyamanan yang diberikan kepada konsumen ketika memberikan informasi. } \\
\text { - Privasi konsumen menjadi perhatian paling utama. } \\
\text { Kepuasan pelanggan adalah kepuasan konsumen tentang layanan-layanan yang } \\
\text { disediakan. } \\
\text { - Tampilan website sesuai dengan harapan konsumen. } \\
\text { - Kurangnya pengalaman dalam memasarkan produk dan jasa. } \\
\text { - } \text { Proses komunikasi yang baik dari website kepada konsumen. } \\
\text { Kepercayaan konsumen adalah kesediaan konsumen untuk melakukan transaksi } \\
\text { pada mitra bisnis yang dapat dipercaya. } \\
\text { - Website bertindak jujur dan dapat dipercaya. } \\
\text { - Menanamkan nilai percaya pada konsumen. } \\
\text { - Kebsite tidak selalu konsisten dengan apa yang dikatakan dan dijanjikan. } \\
\text { - Tidak bersikap opportunis. } \\
\text { Setiap butir pernyataan pada masing-masing variabel di atas disediakan tanggapan te }\end{array}$ & $\begin{array}{l}\text { Jin and Park (2006), } \\
\text { Flavia'n and Guinalı'u } \\
\text { (2006), Roca et al. } \\
\text { (2009), Chung and } \\
\text { Shin (2009, 2010), Eid } \\
\text { (2011). } \\
\text { Flavia'n and Guinalı'u } \\
\text { (2006), Armesh et al. } \\
\text { (2010), Ahmad and Al } \\
\text { Zu'bi (2011), Eid } \\
(2011) \text {. }\end{array}$ \\
\hline
\end{tabular}


Dalam penelitian ini pengumpulan data dilakukan dengan menggunakan angket. Angket penelitian ini berisi butir-butir pernyataan yang sesuai dengan variabel-variabel penelitian tentang persepsi keamanan, persepsi privasi, kepuasan dan kepercayaan konsumen online. Berdasarkan pada penjelasan variabel penelitian yang telah dilakukan, maka dapat dilakukan rekapitulasi konstruk penelitian seperti yang tercantum dalam Tabel 1.

Sebelum digunakan untuk perhitungan dan analisis penelitian, maka data yang diperoleh perlu dilakukan pengujian kualitas data lebih dahulu, dengan uji validitas (kesahehan) dan reliabilitas (keandalan) data. Indikator dan variabel penelitian yang berhasil lolos dari uji kualitas data selanjutnya dianalisis dengan menggunakan dua tahap Analisis Regresi (Model I dan Model II). Alat analisis tersebut sekaligus digunakan untuk membuktikan hipotesis-hipotesis yang telah ditetapkan sebelumnya. Adapun pengambilan kesimpulan dilakukan melalui prosedur pengujian dan dengan enam kriteria pengujian hipotesis berikut: uji-t, uji-F, uji linieritas, uji normalitas data, uji multikolinieritas, dan uji heteroskedastisitas. Semua perhitungan dan analisis pene- litian yang dilakukan ini menggunakan bantuan program pengolah data SPSS versi 17.0.

\section{HASIL PENELITIAN}

Agar supaya memenuhi kriteria data yang berkualias untuk dijadikan sebagai dasar analisis, maka data pada setiap indikator penelitian yang diperoleh perlu dilakukan pengujian validitas (kesahihan data) dan reliabilitas (keandalan data) terlebih. Pengujian validitas dilakukan dengan pendekatan product moment correlation ( $\mathrm{r}$ ) dan dengan menggunakan bantuan program SPSS versi 17.0. Menurut Ghozali (2005) indikator penelitian dapat dikatakan valid, jika diperoleh $\mathrm{r}$ hitung lebih besar dan positif dari pada $r$ tabel $(r h>r t)$. Pada taraf signifikansi $(\alpha)$ 5\% dan derajat kebebasan sebesar 94, maka rt adalah sebesar 0,1688. Sementara itu pengujian reliabilitas dengan menggunakan metode Cronbach Alpha. Suatu variabel yang mempunyai beberapa indikator penelitian bisa dinyatakan reliabel, jika variabel tersebut mempunyai Cronbach's Coefficient Alpha lebih besar atau sama dengan 0,60 ( $\alpha \geq$ 0,60) (Ghozali, 2005). Hasil perhitungan validitas dan reliabilitas dari data yang diperoleh disajikan pada Tabel 2.

Tabel 2: Hasil Perhitungan Validitas dan Reliabilitas Data

\begin{tabular}{|c|c|c|c|}
\hline Butir indikator & $\begin{array}{c}\text { Validitas } \\
\text { (rh) }\end{array}$ & Reliabilitas & Rata-rata \\
\hline Persepsi Keamanan & & 0.643 & 3.49 \\
\hline Memiliki mekanisme pengiriman informasi & 0.636 & & 3.77 \\
\hline Data tidak dapat dimodifikasi oleh hacker & 0.691 & & 3.39 \\
\hline Pembelian tidak menimbulkan masalah keuangan & 0.710 & & 3.28 \\
\hline Pembayaran elektronik aman & 0.744 & & 3.53 \\
\hline Persepsi Privasi & & 0.663 & 3.82 \\
\hline Data pribadi dilindungi secara hukum & 0.627 & & 3.69 \\
\hline Mengumpulkan data pengguna hanya untuk proses transaksi & 0.493 & & 3.64 \\
\hline Data pribadi tidak diberikan kepada orang lain & 0.701 & & 3.58 \\
\hline Merasa aman ketika mengirimkan data pribadi & 0.743 & & 3.78 \\
\hline Situs peduli terhadap privasi pelanggan & 0.707 & & 3.90 \\
\hline Kepuasan & & 0.617 & 3.61 \\
\hline Penampilan situs sesuai harapan & 0.557 & & 3.38 \\
\hline Situs memiliki pengalaman cukup tentang pemasaran & 0.810 & & 3.80 \\
\hline Situs mengenal penggunanya dengan baik & 0.778 & & 3.51 \\
\hline Situs mempunyai sumber daya untuk menjalankan aktifitas & 0.587 & & 3.76 \\
\hline Kepercayaan & & 0.664 & 3.66 \\
\hline Penyedia e - produk dapat dipercaya & 0.560 & & 3.15 \\
\hline Penyedia e - produk menanamkan kepercayaan & 0.751 & & 3.82 \\
\hline Penyedia e-produk memenuhi janji dan komitmen & 0.780 & & 3.67 \\
\hline Memberikan informasi pribadi yang dapat menimbulkan masalah & 0.518 & & 3.91 \\
\hline Situs tidak bersikap opportunis & 0.683 & & 3.77 \\
\hline
\end{tabular}


Dari Tabel 2 dapat diketahui bahwa nilai $r$ hitung pada seluruh butir indikator penelitian menghasilkan nilai yang lebih besar dari 0,1688 . Dengan hasil tersebut, maka dapat dikatakan bahwa seluruh butir dinyatakan memenuhi kriteria kualitas yang valid (sahih). Hasil yang sama diperoleh pada perhitungan reliabilitas. Perhitungan reliabilitas menunjukkan hasil Crobach's Coefficient Alpha lebih besar dari 0,60. Dengan demikian dikatakan variabel-variabel persepsi keamanan, persepsi privasi, kepuasan dan kepercayaan konsumen telah memenuhi kriteria kualitas yang reliabel (andal).

Di samping itu Tabel 2 juga menunjukkan hasil perhitungan rata-rata nilai tanggapan responden pada masing-masing indikator dan variabel penelitian. Berdasarkan pada skala interval data 1 (satu) sampai dengan 5 (lima) dan dibagi dalam 5 rangking penilaian, maka dikatakan bahwa dengan skor rata-rata penilaian responden sebesar 3,49 (interval rangking 3,41 - 4,20) pada variabel persepsi keamanan ini adalah termasuk ke dalam kriteria website yang aman. Sementara itu penilaian tertinggi terjadi pada indikator penilaian tentang website yang memiliki mekanisme pengiriman informasi sebesar 3,77 (aman), sedangkan penilaian terendah diperoleh pada indikator pembelian yang tidak menimbulkan masalah keuangan dengan skor rata-rata sebesar 3,28 atau dinyatakan cukup aman oleh responden (interval 2,61-3,40).

Pada variabel persepsi privasi rata-rata penilaian responden adalah sebesar 3,82, yang termasuk dalam kriteria yang baik. Penilaian tertinggi variabel ini diperoleh pada hasil tanggapan situs yang peduli terhadap privasi pelanggan (skor 3,90, baik), dan penilaian terendah terdapat pada penilian tentang data pribadi yang tidak akan diberikan kepada orang lain (skor 3,58, baik). Sementara itu rata-rata penilaian responden terhadap variabel kepuasan konsumen adalah sebesar 3,61. Nilai tersebut termasuk ke dalam kriteria penilaian responden yang puas. karena berada pada interval 3,41 4,20 . Penilaian kepuasan yang tertinggi dicapai responden dalam menilai situs yang memiliki pengalaman cukup tentang pemasaran, yaitu sebesar 3,80 (puas), sedangkan pada penampilan situs yang dianggap sesuai dengan harapan responden sebesar 3,38 atau cukup puas merupakan indikator hasil penilaian kepuasan responden yang terendah.

Terakhir, skor rata-rata penilaian responden sebesar 3,66 merupakan hasil penilaian pada variabel kepercayaan konsumen yang termasuk ke dalam kriteria website yang dipercaya oleh responden. Selain itu juga diperoleh hasil penilaian tertinggi terjadi pada indikator penilaian tentang kemungkinan memberikan informasi pribadi yang dapat menimbulkan masalah (3,91, percaya). Sedangkan penilaian terendah variabel ini terdapat pada kemungkinan penyedia e-produk yang dapat dipercaya, yaitu dengan skor ratarata sebesar 3,15 (cukup dipercaya).

Tahapan pada analisis berikutnya didasarkan pada pendekatan analisis regresi. Analisis Regresi ini digunakan untuk menguji atau membuktikan hipotesis-hipotesis yang diajukan dalam penelitian ini. Prosedur pengujian menggunakan 6 pendekatan, yaitu uji-t, uji-F, dan uji klasik (linieritas, normalitas data, multikolinieritas, dan heteroskedastisitas). Dengan mengacu pada alternatif pengujian dari Ghozali (2005), maka pengujian $\mathrm{t}$ dan $\mathrm{F}$ didasarkan pada nilai kritis atau tingkat signifikansi $(\alpha) 5 \%$, uji linieritas dengan menggunakan metode Lagrange Multiplier-Engle atau $\mathrm{X}^{2}$ tabel (n-m; $\alpha=5 \%$ ), uji normalitas data menggunakan metode Kolmogorov-Smirnov Z dan ( $\alpha$ ) $5 \%$, uji multikolinieritas dengan pendekatan nilai Tolerance $>0.1$ dan VIF $<10.0$, serta uji heteroskedastisitas didasarkan pada pendekatan Glejser dan $(\alpha) 5 \%$.

Analisis Regresi ini juga menggunakan dua model. Model I adalah regresi dengan variabel bebas persepsi keamanan dan persepsi privasi serta variabel dependen kepuasan. Sedangkan Model II berupa persamaan regresi dengan variabel bebas persepsi keamanan, persepsi privasi, dan kepuasan serta variabel dependen kepercayaan. Hasil rekapitulasi perhitungan regresi kedua model tersebut disajikan dalam Tabel 3 dan 4.

Dari Tabel 3 dapat diketahui bahwa masing-masing koefisien variabel bebas Regresi menghasilkan nilai yang positif dan secara parsial maupun serempak (sig-t dan sigF) mempunyai probabilitas signifikansi hitung kurang dari 5\%. Hal ini berarti Hipotesis (H1 dan H3) yang menyatakan bahwa persepsi kaamanan atau persepsi privasi berpengaruh 
positif terhadap kepuasan telah dapat dibuktikan secara signifikan.

Terbuktinya hipotesis penelitian tersebut lebih dikuatkan oleh terpenuhinya asumsi atau uji klasik Analisis Regresi. Dalam pengujian linieritas model regresi diperoleh nilai perhitungan $\mathrm{X}^{2}$ sebesar -2.016 atau jauh lebih kecil dari $\mathrm{X}^{2}$ tabel (118.136). Hal itu berarti perhitungan Regresi yang dilakukan dengan pendekatan linier dapat digunakan untuk membuktikan hipototesis. Kedua, untuk pengujian normalitas data dapat dihasilkan nilai Kolmogorov-Smirnov Z sebesar 0.907 dan nilai probabilitas signifikansi yang lebih dari $5 \%$, atau 0.383 , sehingga dikatakan data model regresi berdistribusi normal. Sementara itu pengujian multikolieritas antar variabel bebas masing-masing menunjukkan hasil nilai Tolerance lebih besar dari 0.1 dan nilai VIF kurang dari 10.0. Hasil perhitungan tersebut menunjukkan bahwa tidak adanya korelasi yang kuat antara kedua variabel bebas Model I. Terakhir, pengujian heteroskedastisitas dengan pendekatan Glejser menghasilkan probablitas signifikansi lebih dari 5\%, sehingga dapat disimpulkan bahwa Model I Regresi tidak mempunyai gejala heteroskedastisitas. Keempat hasil uji klasik tersebut menguatkan hasil pengujian $\mathrm{t}$ dan $\mathrm{F}$, sekaligus menguatkan terbuktinya hipotesis $\mathrm{H} 1$ dan $\mathrm{H} 3$.
Selanjutnya dari hasil perhitungan koefisien diterminan $\left(\mathrm{r}^{2}\right)$ parsial dapat ditentukan bahwa dari keseluruhan proporsi yang dapat menjelaskan tingkat kepuasan konsumen online, maka sebesar 30,9\% dapat dijelaskan oleh variabel persepsi kaamanan informasi dan transaksi konsumen. Sedangkan untuk persepsi privasi informasi yang didapat konsumen hanya dapat menjelaskan kepuasan sebesar $8,5 \%$. Dengan hasil ini sekaligus dinyatakan bahwa dalam mempengaruhi kepuasan konsumen ternyata persepsi keamanan yang banyak berpengaruh dan dianggap lebih penting oleh konsumen online daripada persepsi privasi mereka.

Rekapitulasi Model II Regresi di Tabel 4 tersebut untuk membuktikan tiga hipotesis, yaitu $\mathrm{H} 2, \mathrm{H} 4$, dan $\mathrm{H} 5$. Hasil perhitungan menunjukkan bahwa ketiga hipotesis yang menyatakan bahwa persepsi kaamanan, persepsi privasi, atau kepuasan berpengaruh positif terhadap kepercayaan secara empirik dapat terbukti. Kesimpulan tersebut didasarkan pada hasil perhitungan pada masing-masing koefisien variabel bebas Regresi yang menghasilkan nilai yang positif dan secara parsial (sig-t) maupun serempak (sig-F) mempunyai probabilitas signifikansi hitung kurang dari $5 \%$.

Tabel 3: Rekapitulasi Model Regresi I dengan Variabel Dependen Kepuasan

\begin{tabular}{lcccccc}
\hline \multicolumn{1}{c}{ Keterangan } & $\begin{array}{c}\text { Koef. } \\
\text { beta }\end{array}$ & Sig-t & Tolerance & VIF & $\begin{array}{c}\text { Heteros. } \\
(\text { Sig.) }\end{array}$ & $\begin{array}{c}\mathrm{r}^{2} \\
\text { partial }\end{array}$ \\
\hline Keamanan & .540 & .000 & .822 & 1.217 & .177 & .309 \\
Privasi & .245 & .004 & .822 & 1.217 & .908 & .085 \\
Sig. uji F & & .000 & & & & \\
Uji linieritas $\left(\mathrm{X}^{2}\right)$ & & -2.016 & & & & \\
Uji normalitas & & $.907(.383)$ & & & & \\
\hline
\end{tabular}

Tabe 4: Rekapitulasi Model Regresi II dengan Variabel Dependen Kepercayaan

\begin{tabular}{lcccccc}
\hline \multicolumn{1}{c}{ Keterangan } & $\begin{array}{c}\text { Koef. } \\
\text { Beta }\end{array}$ & Sig-t & Tolerance & VIF & $\begin{array}{c}\text { Heteros. } \\
\text { (Sig.) }\end{array}$ & $\begin{array}{c}\mathrm{r}^{2} \\
\text { partial }\end{array}$ \\
\hline Keamanan & .360 & .000 & .568 & 1.761 & .913 & .187 \\
Privasi & .166 & .017 & .752 & 1.329 & .163 & .061 \\
Kepuasan & .443 & .000 & .536 & 1.865 & .410 & .247 \\
Sig. uji F & & .000 & & & & \\
Uji linieritas $\left(\mathrm{X}^{2}\right)$ & & -3.072 & & & & \\
Uji normalitas & & $1.145(.145)$ & & & & \\
\hline
\end{tabular}


Untuk menguatkan kesimpulan tersebut dapat dicermati hasil pengujian asumsi klasik Analisis Regresinya. Dari hasil pengujian linieritas model regresi dapat diketahui bahwa nilai $X^{2}$ hitung adalah sebesar -3.072 atau jauh lebih kecil dari $X^{2}$ tabel (118.136). Hasil tersebut menunjukkan bahwa perhitungan Regresi dengan pendekatan linier terdukung secara signifikan.

Perhitungan pengujian normalitas data menunjukkan hasil bahwa data model regresi berdistribusi normal, karena KolmogorovSmirnov Z dapat diperoleh sebesar 1.145 dan nilai probabilitas signifikansi yang lebih dari $5 \%$, atau sebesar 0.145 . Hasil yang sama juga terjadi pada pengujian multikolieritas antar variabel bebas. Masing-masing variabel menunjukkan hasil nilai Tolerance lebih besar dari 0.1 dan nilai VIF kurang dari 10.0. Hasil perhitungan tersebut dapat digunakan untuk menyimpulkan bahwa tidak adanya korelasi yang kuat antara ketiga variabel bebas dari Model II. Sementara itu, dari perhitungan untuk pengujian heteroskedastisitas dapat diperoleh probablitas signifikansi untuk semua variabel bebas adalah lebih dari 5\%, sehingga dinyatakan bahwa Model II Regresi mempunyai gejala homoskedastisitas, atau sebaliknya tidak mempunyai gejala heteroskedastisitas.

Dengan hasil keempat uji klasik asumsi Regresi tersebut menunjukkan bahwa pengujian $\mathrm{t}$ dan $\mathrm{F}$ terdukung secara analitis, sekali- gus menguatkan terbuktinya hipotesis $\mathrm{H} 2, \mathrm{H} 4$, dan H5.

Dengan kesimpulan tersebut di atas, maka hasil perhitungan koefisien diterminan $\left(r^{2}\right)$ parsial menjadi penting dalam analisis penelitian ini. Dari ketiga variabel bebas yang berpengaruh terhadap kepercayaan konsumen online, ternyata kepuasan konsumen dapat menjelaskan keberadaan keperyaan dengan proporsi sebanyak $24,7 \%$, persepsi keamanan $18,7 \%$, dan persepsi privasi hanya sebesar $6,1 \%$. Hasil koefisien determinan ini menunjukkan dominasi dan sekaligus pentingnya kepuasan konsumen online dalam membangun kepercayaan mereka, terutama jika dikaitkan sebagai dasar untuk berupaya menggalang kerja sama jangka panjang antara penjual atau produsen dengan konsumen online. Hasil ini juga menguatkan kesimpulan dari Model I Analisis Regresi penelitian ini bahwa persepsi privasi informasi konsumen masih dianggap kurang penting dibandingkan dengan persepsi keamanan mereka.

Dari hasil penelitian dengan menggunakan Model I dan Model II tersebut dapat dilakukan rekapitulasi pengujian hipotesis seperti yang tercantum dalam Gambar 2. Berdasarkan pada Gambar 2 tersebut, selanjutnya dapat dilakukan perhitungan besarnya pengaruh total, langsung maupun tidak langsung dari variabel persepsi keamanan dan persepsi privasi terhadap kepuasan dan kepercayaan konsumen online, yaitu seperti yang tercantum dalam Tabel 5.

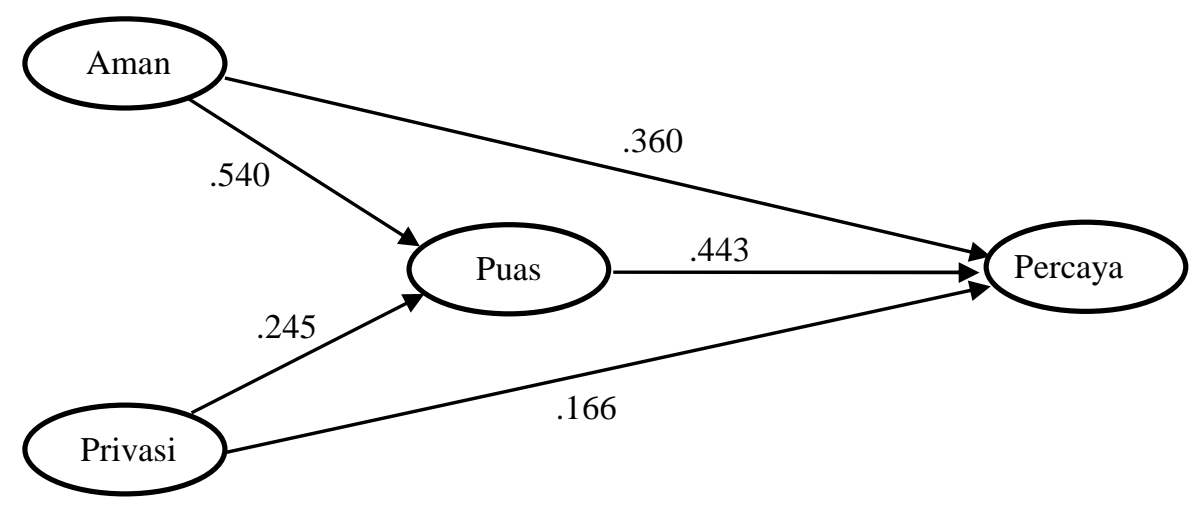

Gambar 2: Hasil Model Penelitian

Tabel 5: Pengaruh Variabel Bebas

\begin{tabular}{lccccccccc}
\hline \multirow{2}{*}{ Var. } & \multicolumn{3}{c}{ Pengaruh total } & \multicolumn{3}{c}{ Pengaruh langsung } & \multicolumn{3}{c}{ Pengaruh tak langsung } \\
\cline { 2 - 10 } & Aman & Privasi & Puas & Aman & Privasi & Puas & Aman & Privasi & Puas \\
Puas & .540 & .245 & & .540 & .245 & & & & \\
Percaya & .599 & .275 & .443 & .360 & .166 & .443 & .239 & .109 & \\
\hline
\end{tabular}


Kolom depan di Tabel 5 menunjukkan besarnya proporsi pengaruh total persepsi keamanan terhadap kepuasan adalah sebesar 0.540 . Besarnya pengaruh total tersebut tidak lain adalah sebesar nilai pengaruh langsung dari persepsi keamanan terhadap kepuasan yang ditunjukkan pada kolom tengah. Nilai tersebut dapat berarti bahwa dari semua aspek yang mungkin mempengaruhi kepuasan konsumen online, maka sebesar $54 \%$ dipengaruhi secara positif oleh privasi keamanan, sementara sisanya $(46 \%)$ dipengaruhi oleh variabel-variabel lain yang tidak dimaksukkan atau dianggap konstan dalam model penelitian pengaruh tersebut. Penjelasan yang sama dapat dijabarkan untuk proporsi pengaruh total persepsi privasi terhadap kepuasan serta proporsi pengaruh total kepuasan terhadap kepercayaan.

Sementara itu proporsi pengaruh total persepsi keamanan terhadap kepercayaan konsumen adalah sebesar 0.599. Besarnya nilai tersebut diperoleh dari penjumlahan proporsi pengaruh langsung (0.360) dan proporsi pengaruh tidak langsung (0.239). Sedangkan besarnya proporsi pengaruh tidak langsung tersebut berasal dari perkalian antara proporsi pengaruh langsung persepsi keamanan terhadap kepuasan (0.540) dengan proporsi pengaruh langsung kepuasan terhadap kepercayaan (0.443). Logika analisis yang sama diberlakukan untuk menjelaskan besarnya proporsi pengaruh total persepsi privasi terhadap kepercayaan.

Dengan hasil tersebut, maka besarnya proporsi pengaruh total persepsi keamanan dan privasi terhadap kepercayaan konsumen online diperoleh dari penjumlahan tiga komponen perhitungan. Pertama, perkalian antara rata-rata proporsi pengaruh persepsi keamanan dan privasi terhadap kepuasan dengan proporsi pengaruh kepuasan terhadap kepercayaan. Kedua, besarnya proporsi pengaruh persepsi keamanan terhadap kepercayaan. Ketiga, besarnya proporsi pengaruh persepsi privasi terhadap kepercayaan. Hasil perhitungan tersebut adalah sebesar 0.700, yang diperoleh dari rincian sebagai berikut:

$\{[(0.540+0.245) / 2] \times 0.443\}+0.360+0.166$ $=0.700$

Nilai proporsi pengaruh total tersebut dapat berarti bahwa dari semua kemungkinan faktor-faktor yang bisa mempengaruhi kepercayaan konsumen online maka sebesar
$70 \%$ dipengaruhi secara positif oleh privasi keamanan, sementara sisanya (30\%) dipengaruhi oleh variabel-variabel lain yang tidak dimasukkan atau dianggap konstan dalam model penelitian ini.

\section{PEMBAHASAN}

Penelitian ini telah berhasil mengungkap dugaan sebelumnya tentang dampak positif dari persepsi keamanan dan privasi terhadap kepuasan dan kepercayaan konsumen yang mendapatkan penawaran dan pemasaran produk melalui media internet atau online (ecommerce). Hal ini dibuktikan dengan terpenuhinya secara signifikan hasil pengujian lima hipotesis yang diajukan dalam penelitian ini dengan menggunakan dua model Analisis Regresi.

Hasil model I Analisis Regresi membuktikan bahwa persepsi keamanan dan privasi berpengaruh positif terhadap kepuasan. Hasil penelitian ini sesuai dengan bukti empiris yang diperoleh dari hasil penelitian Jin and Park (2006) serta Ahmad and Al Zu'bi (2011). Hal ini berarti bahwa semakin baik persepsi keamanan dan privasi konsumen online akibat penawaran penjual atau produsen, maka semakin tinggi pula kepuasan yang akan diterima oleh konsumen tersebut.

Jika dibandingkan, dari kedua variabel bebas yang ada tersebut dominasi persepsi keamanan menunjukkan pentingnya variabel itu perlu lebih diperhatikan dibandingkan dengan persepsi privasi. Sembari tetap berusaha untuk meningkatkan layanan privasi kepada konsumen online-nya agar kepuasan konsumen tersebut menjadi bertambah, maka indikator utama yang diperlukan untuk mempertahankan dominasi persepsi keamanan tersebut adalah pada aspek mekanisme pengiriman informasi. Pengelola website sebaiknya memberikan informasi yang jelas tentang proses pengiriman informasi pribadi oleh konsumen kepada penyedia layanan jasa $e$ commerce, sehingga tidak terjadai kebocoran data pribadi konsumen kepada pihak ketiga. Artinya pihak pengelola situs e-commerce memberikan jaminan bahwa data-data pribadi pembeli tetap akan dijaga dan tidak digunakan oleh pihak ketiga yang akan merugikan konsumen. Selain itu pengelola layanan jasa $e$ commerce perlu juga meningkatkan indikator 
yang dinilai rendah oleh konsumen, yaitu yang berkaitan dengan pembelian agar tidak menimbulkan masalah keuangan. Pembayaran lewat rekening/ATM biasanya dikenakan biaya, oleh karena itu pihak pengelola situs e-commerce hendaknya menawarkan produk dengan harga bersaing, artinya harga di belanja online tidak lebih mahal daripada harga toko fisik atau manual.

Sementara itu untuk meningkatkan nilai persepsi privasi agar dapat memberikan kepuasan konsumen online yang lebih tinggi, maka penjual atau produsen toko online sebagai penyedia layanan e-commerce sebaiknya tetap mempertahankan atau bahkan perlu meningkatkan indikator yang dinilai paling tinggi oleh konsumen, yaitu perlunya penyedia layanan perduli terhadap privasi pelanggan, karena privasi pelanggan sangat penting dalam suatu hubungan bisnis antara penjual dan pembeli. Hal ini dapat dilakukan misalnya dengan memberi penghargaan kepada konsumen untuk menetapkan pilihan kesediaan atau keengganan mendapatkan informasiinformasi penting dan rutin dari penyedia. Di samping itu hendaknya pengelola layanan jasa e-commerce perlu juga meningkatkan indikator yang dalam penelitian ini masih dinilai rendah oleh konsumen, yaitu tentang perlunya jaminan data pribadi yang tidak akan diberikan kepada orang lain. Hal ini bisa dilakukan misalnya dengan cara pihak pengelola situs e-commerce memberi jaminan secara transparan kepada konsumen bahwa data-data pribadinya tidak akan diberikan kepada pihak ketiga, selain adanya jaminan pengelola situs memiliki keamanan bahwa data pribadi konsumen tidak bisa diakses oleh hacker.

Pada Model II Analisis Regresi dapat diperoleh hasil pengujian hipotesis-hipotesis yang signifikan, yaitu adanya pengaruh positif persepsi keamanan, persepsi privasi dan kepuasan terhadap kepercayaan konsumen online. Hipotesis yang berhasil dibuktikan dalam penelitian ini mendukung hasil penelitian empiris yang telah dilakukan sebelumnya, seperti misalnya oleh Flavia'n and Guinalı'u (2006) serta Chung and Shin (2009, 2010). Dengan kata lain, jika persepsi keamanan, persepsi privasi, dan kepuasan konsumen online akibat penawaran penjual atau produsen dapat menghasilkan nilai yang baik pada diri konsumen, maka semakin tinggi pula harapan untuk memperoleh kepercayaan yang akan diterima oleh penjual atau produsen dari konsumen tersebut.

Hasil pembuktian hipotesis-hipotesis tersebut mencerminkan tiga hal penting. Pertama dari ketiga variabel bebas yang ada ternyata kepuasan mencapai dominasi tertinggi dibandingkan dengan persepsi keamanan dan persepsi privasi dalam mempengaruhi kepercayaan konsumen online. Untuk mempertahankan dominasi tersebut penyedia layanan $e$ commerce sebaiknya tetap mempertahankan atau bahkan meningkatkan indikator yang dinilai paling tinggi oleh konsumen, yaitu memberi keyakinan bahwa penyedia layanan memiliki pengalaman yang cukup dalam memasarkan produk yang ditawarkan. Hal ini misalnya bisa di lakukan dengan menerapkan strategi yang baru dan selalu berubah-ubah dalam memasarkan produknya melalui $e$ commerce. Pihak pengelola situs di $e$ commerce juga perlu menjelaskan secara spesifik produk yang ditawarkan dan kualitas produk yang sesuai dengan kenyataan. Di samping itu pengelola layanan e-commerce juga perlu meningkatkan indikator yang masih dinilai rendah oleh konsumen, yaitu yang berkaitan dengan penampilan situs yang sesuai dengan harapan konsumen. Hal ini dapat dilakukan misalnya dengan cara menambah variasi tampilan dalam website menambah animasi atau variasi warna. Penampilan situs mungkin perlu dibuat secara sederhana, namun menarik dan mempunyai petunjuk atau cara menggunakannya, sehingga konsumen mudah mengakses situs yang bersangkutan.

Kedua, urutan dominasi berikutnya setelah kepuasan dalam mempengaruhi tingkat kepercayaan konsumen online adalah persepsi keamanan, dan kemudian persepsi privasi. Urutan ini searah dengan dominasi kedua variabel anteseden tersebut ketika mempengaruhi kepuasan konsumen online. Implikasi dari hasil penelitian juga searah dengan penjelasan pada bagian tersebut. Ketiga, pentingnya faktor kepuasan yang dinilai lebih penting bagi konsumen dalam menyumbang kepercayaan mereka ini dibandingkan dengan faktor anteseden dalam model penelitian ini perlu mendapat perhatian khusus dari penyedia layanan e-commerce, karena jika konsumen mendapatkan nilai melebihi apa yang dibayarkan, konsumen akan merasa puas dan yakin akan 
pelayanan yang diberikan. Selain itu dalam konteks penelitian ini kepuasan yang merupakan variabel endogen pertama bisa menjadi faktor anteseden utama yang menjadi dasar dalam membina hubungan jangka panjang antara penyedia layanan e-commerce dengan konsumen online. Dengan kata lain kepuasan konsumen bisa menjadi prasyarat yang diperlukan untuk membentuk loyalitas konsumen, yang pada gilirannya nanti akan menjadi faktor yang dapat mendorong dalam pertumbuhan kinerja dan laba penyedia layanan e-commerce. Implikasi yang lain dalam penelitian ini adalah untuk membuat konsumen merasa terpuaskan dalam bertransaksi, terlebih untuk menciptakan rasa kepercayaan pada konsumen, para penjual barang yang menjual barang dagangan atau produknya melalui layanan internet atau sistem online harus selalu memperhatikan privasi konsumen dan resiko keamanan yang ditimbulkan ketika hendak bertransaksi sehingga dapat membuat nyaman dan menarik minat konsumen untuk membuat transaksi dengan penjual atau produsen online.

Saran tersebut menjadi lebih penting untuk diperhatikan karena dari hasil perhitungan proporsi pengaruh total yang dilakukan menunjukkan bahwa persepsi keamanan dan privasi sebagai faktor anteseden dalam penelitian ini mampu memberi sumbangan sebesar $70 \%$ dari kemungkinan faktor-faktor yang berpengaruh terhadap kepercayaan konsumen dalam menggunakan media online dalam memenuhi kebutuhan dan keinginan mereka. Besarnya sumbangan tersebut merupakan nilai yang sangat signifikan pada suatu penelitian sosial, yang secara kondisional sebetulnya dipengaruhi oleh banyak faktor eksogen.

\section{PENUTUP}

Penelitian ini telah berhasil membuktikan hipotesis-hipotesis penelitian yang diajukan, sekaligus berhasil mendukung hasil penelitian empiris sebelumnya. Meskipun telah melibatkan penelitian survei dengan berbagai obyek layanan e-commerce, namun penelitian ini juga masih dianggap mempunyai kelemahan. Pertama dari sisi subyek penelitian yang hanya menggunakan populasi mahasiswa suatu fakultas di suatu PTS di Yogyakarata yang sudah pernah melakukan transaksi online serta hanya menggunakan sampel yang relatif sedikit. Ke depan dimungkinkan dikembangkan suatu penelitian yang menggunakan subyek penelitian dengan profesi yang lebih beragam dan dengan jumlah sampel yang lebih banyak. Berbagai kemungkinan penambahan tersebut dimaksudkan agar model penelitian dapat lebih teruji.

Kedua, penelitian ini menggunakan pendekatan Analisis Regresi secara bertahap dan dengan bantuan Program SPSS versi 17.0. Meskipun secara metodologik tidak ada aturan yang dilanggar atau salah, apalagi masih cukup banyak penelitian sosial yang dilakukan dengan pendekatan ini, namun mungkin akan lebih tepat jika pada penelitian sejenis berikutnya menggunakan pendekatan structural equation modelling (SEM) dan dengan bantuan program pengolah data LISREL, AMOS, PLS atau sejenisnya.

Ketiga, penelitian ini menggunakan faktor anteseden berupa persepsi keamanan dan persepsi privasi. Padahal sangat mungkin masih ada beberapa variabel penting lain yang dapat berpengaruh pada kepuasan dan kepercayaan konsumen online. Oleh karena pada penelitian selanjutnya perlu dipertimbangkan untuk melibatkan variabel lain dalam model penelitian, seperti kualitas informasi dan desain dari website, serta kemudahan dalam mengakses dan reputasi penyedia layanan $e$ commerce

\section{DAFTAR PUSTAKA}

Ahmad, AEMK. and HA. Al Zu'bi. 2011. Ebanking Functionality and Outcomes of Customer Satisfaction. An Empirical Investigation. International Journal of Marketing Studies. 3 (1). 50-65

Armesh, H., H. Salarzehi, NM. Yaghoobi, A. Heydari and D. Nikbin. 2010. The Effects of Security and Privacy Information on Trust and Trustworthiness and Loyalty in Online Marketing in Malaysia, International Journal of Marketing Studies. 2 (2). 223-234

Chung, KH. and JI. Shin. 2008. The Relationship among e-Retailing Attributes, eSatisfaction and e-Loyalty. Management Review: an International Journal. 3 (1). 23-45 
Chung, KH. and JI. Shin. 2009. The Relationship Between Site Characteristics, Relationship Quality, and Word of Mouth. International Journal of Business and Information. 4 (2). 137-160

Chung, KH. and JI. Shin. 2010. The Antecedents and Consequents of Relationship Quality in Internet Shopping. Asia Pacific Journal of Marketing and Logistics. 22 (4). 473491

Eid, MI. 2011. Determinants of E-commerce Customer Satisfaction, Trust, and Loyalty in Saudi Arabia. Journal of Electronic Commerce Research. 12 (1). 78-93.

Flavia'n, C. and M. Guinali'u. 2006. Consumer Trust, Perceived Security and Privacy Policy Three Basic Elements of Loyalty to a Web Site. Industrial Management \& Data Systems. 106 (5). 601-620

Ghozali, I. 2005. Aplikasi Analisis Multivariate dengan program SPSS. Semarang: Badan Penerbit Universitas Diponegoro.

Jin, B. and JY. Park. 2006. The Moderating Effect of Online Purchase Experience on the Evaluation of Online Store
Attributes and the Subsequent Impact on Market Response Outcomes. Advances in Consumer Research. 33. 203-211

Kassim, N. and NA. Abdullah. 2010. The Effect of Perceived Service Quality Dimensions on Customer Satisfaction, Trust, and Loyalty in e-commerce Settings. Asia Pacific Journal of Marketing and Logistics. 22 (3). 351371

Kotler, P. and KL. Keller. 2009. Marketing Management. $13^{\text {th }}$ ed. New Jersey: Pearson Prentice Hall

Roca, JC., JJ. Garci'a and JJ. de la Vega. 2009. The Importance of Perceived Trust, Security and Privacy in Online Trading Systems. Information Management \& Computer Security. 17 (2). 96-113

Rofiq, A. 2007. Pengaruh Dimensi Kepercayaan (Trust) terhadap Partisipasi Pelanggan E-commerce (Studi Pada Pelanggan E-commerce di Indonesia). Tesis Magister Manajemen (Tidak dipublikasikan). Malang: Program Pascasarjana Universitas Brawijaya.

Tjiptono, F. 2000. E-commerce. Memikat Sekaligus Mengikat. Buletin Jendela Informatika. 1 (5). 1-3. 